Ethics in an Epidemic 



\section{Ethics in}

\section{an Epidemic}

AIDS, Morality, and Culture

Timothy F. Murphy

UNIVERSITY OF CALIFORNIA PRESS

Berkeley / Los Angeles / London 
University of California Press

Berkeley and Los Angeles, California

University of California Press

London, England

Copyright (C) 1994 by The Regents of the University of California

Library of Congress Cataloging-in-Publication Data

Murphy, Timothy F., 1954-

Ethics in an epidemic : AIDS, morality, and culture / Timothy

F. Murphy.

p. $\mathrm{cm}$.

Includes bibliographical references and index.

ISBN 0-520-08636-8 (alk. paper)

1. AIDS (Disease)-Moral and ethical aspects. 2. AIDS

(Disease)-Social aspects. 3. AIDS (Disease)-Government policy-United States. I. Title.

RA644.A25M87 1994

$362.1^{\prime} 969792-\mathrm{dc} 20$

94-8248

CIP

Printed in the United States of America

$\begin{array}{lllllllll}1 & 2 & 3 & 4 & 5 & 6 & 7 & 8 & 9\end{array}$

The paper used in this publication meets the minimum requirements of American National Standard for Information Sciences-Permanence of Paper for Printed Library Materials, ANSI Z39.48-1984@ 